\title{
Review of Wadi Sura-The Cave of Beasts edited by Rudolph Kuper
}

\author{
Robin Bendrey
}

\author{
Book details \\ Kuper, R (ed.) \\ Wadi Sura-The Cave of Beasts. \\ Köln: Heinrich-Barth-Institut; 2013. \\ 542 pages, 545 full colour pages, size $24 \times 34 \mathrm{~cm}$, hardcover and half linen-bound, 2 folded plates, \\ ISBN: 978-3-927688-40-7
}

Keywords: Rock art; Africa; Prehistory; Eastern Sahara; Ancient Egypt; Hunter-gatherers; Early and Middle Holocene; Pastoralism

\section{Main text}

The substantial corpus of rock art of the Gilf Kebir, a sandstone massif in the far southwest of Egypt, provides a rich insight into one of the major changes in the human past - the transition from hunting animals to herding them. Evidence for this transition comes from a number of sources - not only from archaeological remains, such as animal bones and artefacts, but also from the rock art images themselves. This volume focuses on one site from this area, the rock shelter 'Cave of Beasts' (Wadi Sura site II), located at the foot of the Gilf Kebir and discovered in 2002; but it also places the site and its art in its full regional and chronological context. The regional trajectory of human prehistory is summarised in a chapter by Kuper, the editor of the volume, who identifies the earliest adoption of domestic livestock across the Eastern Sahara in the period c. 7,000 to 6,000 BC. Kuper also introduces the volume and lays out the context, rationale and execution of the Cologne Wadi Sura Project of work on the Cave of Beasts. It is one of the richest rock art sites in the Sahara with around 8,000 figures (Wadi Sura means 'valley of the pictures' in Arabic).

This volume consists of two parts: the first, around 80 pages long, contains a series of short chapters on the site, its study and its wider context; the second, some

Correspondence: r.bendrey@reading.ac.uk

Department of Archaeology, University of Reading, Whiteknights Box 226, Reading RG6 6AB, UK

\section{黑 Springer}

(C) 2014 Bendrey; licensee Springer. This is an Open Access article distributed under the terms of the Creative Commons Attribution License (http://creativecommons.org/licenses/by/2.0), which permits unrestricted use, distribution, and reproduction in any medium, provided the original work is properly cited.
450 pages long, is a complete catalogue of the paintings and engravings the site contains.

The book's authors consider both the artistic images themselves and the broader archaeological record in order to contextualise long-term changes and human responses to fluctuating climatic conditions. These transformed the Sahara from hyper-arid and uninhibited during the 9th millennium BC into a Savannah-like environment by a monsoonal rain front from the south. The Eastern Sahara was subsequently re-occupied by human groups, who were pottery-using hunter-gatherers. After the appearance of the first domestic livestock (c. 7,000 to 6,000 BC), this was followed from c. 5,300 $\mathrm{BC}$ by the retreat of the monsoonal rains and the return of desert conditions in the northern part of the Eastern Sahara. This latter climatic change forced human communities to move to more favourable locations in the south and along the Nile Valley to the east. Within the region of the Eastern Sahara, favourable climatic conditions seem to have persisted longer in the mountainous areas such as the Gilf Kebir and nearby Jebel Ouenat, and it is to this period (c. 6,500 to 4,400 BC) that the Cave of Beasts rock art is attributed. Riemer's first solely authored chapter deals with the challenge of dating the Wadi Sura rock art, through a consideration of regional settlement context, pottery typology and radiocarbon dating.

The rock art subject matter, produced by huntergatherer communities, differs completely from that of the succeeding cattle pastoralists after c. 4,400 BC. Numerous 
wild animals are represented in the rock shelter, such as ostrich, giraffe and gazelle. Reimer writes that although animal bones are poorly preserved, gazelle, antelope and giraffe remains have been excavated from contemporaneous sites in the region. Although these point to the dominance of hunted meat in the diet, Riemer states that it cannot be excluded that meat from goat or sheep keeping constituted a minor part of the diet from the 6th millennium BC (making them 'pastro-foragers', as he terms them). However, the shift to a greater reliance on domestic animals, in either economic or ideological terms, is not hypothesised until after c. 4,400 BC (see Kuper and Riemer 2013).

This ideological transition can be seen in the shift between the two major artistic style complexes in the Gilf Kebir - from one characterised by the abstract 'headless beasts' and human 'swimmers' to the naturalistic representations of the 'cattle pastoralists' (the latter are few at Wadi Sura) - and may provide a window into the profound transformations occurring within human societies moving from hunting wild animals to herding domestic livestock (Russell 2012, p. 207-258). The Wadi Sura rock art in its regional context is the subject of Zboray's chapter. Zboray gives a concise review of the regional styles and the attribution of chronologies and possible interrelationships. Relative chronologies are teased out from studies of superimpositions of rock art, where one complex is superimposed over a pre-existing scene. In the Wadi Sura area, there are four known sites where cattle pastoralist figures are painted over Wadi Sura type figures. Several further chapters specifically consider the site in its wider context, with essays outlining the archaeological survey work undertaken around the area of Wadi Sura (Riemer and Bartz), exploring and understanding the location of rock art within the local landscape (Reimer), and understanding Wadi Sura in its full environmental setting (Darius).

The presentation of the pictures of the rock art itself constitutes the bulk of the book. A half natural size (1:2) scale was chosen for reproduction, which allows for the presentation of all details, while permitting the collection to be published in one volume.

The project represents a considerable achievement in the development and application of scientific methods for recording and analysing the rock art. Chapters describe the innovative techniques applied to record the images (Lesien, Krause, Reimer, Seidel and Büttner), understanding the complex compositions and superimpositions of figures on the panels (also by Föster), and a study of the paints and pigments used in the rock art (Krause, Reimer and Leisen).

Förster and Kuper's chapter on the 'myths and messages' of the rock art acknowledges that the complex of Wadi Sura images can offer rich insights into both sacred and profane aspects of the lifeways of the communities that created this art; but they are keen to resist premature and over-interpretation of the images. In fact, Förster and Kuper argue that fast and uncritical publication can be detrimental to scientific progress, and they use much of their chapter to disabuse the reader of a number of recently published interpretations of the Wadi Sura imagery. In support of this, they quote Rhotert (1952), who studied Libyan rock art in the 1930s:

"Quite too often we live to see in science that a suggestion, once enunciated, is taken by other authors as a fact and asserts itself stubbornly as a truth eating bacillus, even if the first author had for a long time disavowed his misunderstood statement" (p. 26-27; Förster and Kuper translation).

This underlines the laudable purpose and scientific method of the volume, in that the images are being published in their entirety as the foundation for their study. The project is also concerned with the conservation of the site and its images and two chapters explicitly reflect on this: with one on the conservation of the rock art (Leisen and Krause) and one on the impacts of desert tourism (Kuper).

This is a beautiful volume, produced to a very high standard, which is a credit to the authors, the publisher, and the funders who made it possible. There are only a few very minor criticisms - there are occasional syntax errors and it would also have been good to include the affiliations of the individual authors - but these do not really detract from the academic or aesthetic qualities of the book. The primary aim of the book is to make the complete sequence of the paintings and engravings available for study and enjoyment. In these aims this volume has been entirely successful. The rich corpus of rock art illustrating the lives and concerns of the prehistoric huntergatherers and early pastoralists of the Eastern Sahara, published here for all to access, really captures the imagination and is simply a joy to look at as well as to study.

\section{Competing interests}

The author declares that he has no competing interests.

Received: 8 December 2013 Accepted: 9 January 2014 Published: 22 Jan 2014

\section{References \\ Kuper, R, and H Riemer. 2013. Herders before pastoralism: Prehistoric prelude in the Eastern Sahara. In Pastoralism in Africa: Past, present and future, ed. M Bollig, M Schnegg, and H-P Wotzka, 31-65. New York/Oxford: Berghahn. Rhotert, H. 1952. Libysche Felsbilder: Ergebnisse der XI. und XII: Deutschen Inner-Afrikanischen Forschungs-Expedition (DIAFE) 1933/1934/1935. Frankfurt am Main: Veroffentlichung des Frobenius-Instituts an der Johann Wolfgang Goethe-Universitat. Darmstadt: L.C. Wittich. \\ Russell, N. 2012. Social zooarchaeology: Humans and animals in prehistory. Cambridge: Cambridge University Press.}

10.1186/2041-7136-4-2

Cite this article as: Bendrey: Review of Wadi Sura-The Cave of Beasts edited by Rudolph Kuper. Pastoralism: Research, Policy and Practice $2014,4: 2$ 